\section{Radiation Intensity and Quality Affect Indoor Acclimation of Blueberry Transplants}

\author{
Celina Gómez, Megha Poudel, Matias Yegros, and Paul R. Fisher \\ Environmental Horticulture Department, University of Florida, Institute \\ of Food and Agricultural Sciences (IFAS), 1549 Fifield Hall, Gainesville, \\ FL 32611-0670
}

Additional index words. controlled environments, indoor farming, indoor propagation, LED, sole-source lighting, vertical farming

\begin{abstract}
The objectives were to characterize and compare shrinkage (i.e., transplant loss) and growth of tissue-cultured blueberry (Vaccinium corymbosum) transplants acclimated in greenhouses or indoors under 1) different photosynthetic photon flux densities (PPFDs) (Expt. 1); or 2) spectral changes over time using broad-spectrum white (W; 400 to $700 \mathrm{~nm}$ ) light-emitting diodes (LEDs) without or with red or far-red (FR) radiation (Expt. 2). In Expt. 1, 'Emerald' and 'Snowchaser' transplants were acclimated for 8 weeks under PPFDs of $35,70,105$, or $140 \pm 5 \mu \mathrm{mol} \cdot \mathrm{m}^{-2} \cdot \mathrm{s}^{-1}$ provided by W LED fixtures for $20 \mathrm{~h} \cdot \mathrm{d}^{-1}$. In another treatment, PPFD was increased over time by moving transplants from treatment compartments providing 70 to 140 $\mu \mathrm{mol} \cdot \mathrm{m}^{-2} \cdot \mathrm{s}^{-1}$ at the end of week 4 . Transplants were also acclimated in either a research or a commercial greenhouse (RGH or CGH, respectively). Shrinkage was unaffected by PPFD, but all transplants acclimated indoors had lower shrinkage $(\leq 4 \%)$ than those in the greenhouse $(15 \%$ and $17 \%$ in RGH and CGH, respectively), and generally produced more shoot and root biomass, regardless of PPFD. Growth responses to increasing PPFD were linear in most cases, although treatment effects after finishing were generally not significant among PPFD treatments. In Expt. 2, 'Emerald' transplants were acclimated for 8 weeks under constant $W, W+$ red (WR), or W + FR (WFR) radiation, all of which provided a PPFD of $70 \pm 2$ $\mu \mathrm{mol} \cdot \mathrm{m}^{-2} \cdot \mathrm{s}^{-1}$ for $20 \mathrm{~h} \cdot \mathrm{d}^{-1}$. At the end of week 4, a group of transplants from WR and WFR were moved to treatment compartments with $W\left(W R_{W}\right.$ or $W F R_{W}$, respectively) or from $W$ to a research greenhouse $\left(W_{G H}\right)$, where another group of transplants were also acclimated for 8 weeks (GH). Shrinkage of transplants acclimated indoors was also low in Expt. 2, ranging from 1\% to $4 \%$. In contrast, shrinkage of transplants acclimated in $\mathrm{GH}$ or under $\mathrm{W}_{\mathrm{GH}}$ was $37 \%$ or $14 \%$, respectively. Growth of indoor-acclimated transplants was generally greater than that in GH or under $\mathrm{W}_{\mathrm{GH}}$. Although growth responses were generally similar indoors, plants acclimated under WFR had a higher root dry mass (DM) and longer roots compared with GH and $\mathbf{W}_{\mathbf{G H}}$.
\end{abstract}

Most specialty crops produced in the United States are propagated in greenhouses. Problems with daily and seasonal environmental changes during greenhouse propagation can lead to slow rooting, inconsistent

Received for publication 9 Aug. 2021. Accepted for publication 13 Sept. 2021.

Published online 11 November 2021.

Financial support was received from the U.S. Department of Agriculture (USDA) National Institute of Food and Agriculture, Multistate Research Project NE1835: Resource Optimization in Controlled Environment Agriculture, the USDA-Agricultural Research Service Floriculture and Nursery Research Initiative \#58-3607-8-725, and industry partners of the Floriculture Research Alliance at the University of Florida (floriculturealliance.org). We thank AgriStarts for donating planting material and Alec Goff for experimental and technical assistance. C.G. is the corresponding author. E-mail: cgomezv@ ufl.edu.

This is an open access article distributed under the CC BY-NC-ND license (https://creativecommons. org/licenses/by-nc-nd/4.0/). greenhouse growers in the United States are considering the adoption of sole-source lighting for indoor propagation (Greenhouse Grower, 2020). Gibson et al. (2020) found that industry stakeholders are particularly interested in acclimating tissue culture (TC) transplants indoors. That is because the ex vitro acclimation process requires TC transplants to adjust to rapid changes in environmental conditions, which can be challenging to achieve in a greenhouse for some species and cultivars that require long periods of adjustment.

Blueberries, a specialty crop with an estimated U.S. value of $\$ 822 \mathrm{M}$ (USDA, 2018), are typically propagated through TC in a laboratory, followed by an acclimation phase under mist irrigation in a greenhouse. Although protocols have been developed to optimize in vitro micropropagation (Debnath and Goyali, 2020; Guo et al., 2019; Zimmerman and Broome, 1980), few published studies have evaluated methods to improve acclimation and reduce shrinkage after TC blueberries are transplanted ex vitro (Hung et al., 2016; Isutsa et al., 1994; Zobayed, 2020). The delicate nature of these transplants makes them highly susceptible to dehydration during greenhouse acclimation; therefore, up to $70 \%$ of shrinkage is common when blueberry transplants are moved to a greenhouse, particularly during the summer (T. Strode, personal communication).

Understanding growth limits of TC transplants like blueberry in response to radiation intensity (often measured as PPFD, 400 to $700 \mathrm{~nm}$ ) is necessary, particularly considering that they are susceptible to various stresses before roots fully develop. Furthermore, rooting responses ultimately determine the capacity of most transplants to benefit from PPFDs that are conducive to faster growth indoors (He, 2020). Radiation quality (i.e., color, spectra) also has great potential to affect developmental processes that can lead to faster rooting and growth. For example, red (600 to $700 \mathrm{~nm}$ ) and FR (700 to $800 \mathrm{~nm}$ ) radiation may stimulate root formation of transplants due to phytochrome-mediated responses that regulate the development of root primordia (Christiaens et al., 2019). However, FR radiation tends to increase stem elongation and, thus, may not be desirable throughout the entire propagation period.

The objectives of this study were to characterize and compare shrinkage and growth of TC blueberry transplants acclimated in greenhouses or indoors under 1) different PPFDs (Expt. 1); or 2) spectral changes over time using broad-spectrum W (400 to 700 $\mathrm{nm}$ ) LEDs without or with red or FR radiation (Expt. 2). We hypothesized that intermediate-to-high PPFDs used indoors would accelerate and increase growth compared with a low PPFD or greenhouse propagation. We further hypothesized that FR radiation would promote early root formation, resulting in lower shrinkage and more growth compared with indoor acclimation under $\mathrm{W}$ without or with red radiation or greenhouse propagation.

\section{Materials and Methods}

Plant material and early culture. In Expt. 1, TC 'Emerald' and 'Snowchaser' highbush blueberries were received from a commercial transplant supplier (AgriStarts, Apopka, FL) on 14 Feb. 2019. Industry standard, 288-cell propagation trays $(5 \mathrm{~mL}$ individual cell volume; Blackmore Co., Belleville, MI) were cut into 20 -cell $(4 \times 5)$ partial trays, filled with $100 \%$ unlimed blond Canadian Sphagnum peat (Premier Tech, Quebec, Canada), and sub-irrigated with $0.14 \mathrm{~L} \cdot \mathrm{m}^{-3}$ wetting agent (AquaGro $2000 \mathrm{M}$; Aquatrols, West Deptford, NJ). For each cultivar, 20 uniform 
unrooted transplants with a single 2- to $3-\mathrm{cm}$ tall stem were removed from their vessel and planted one plant per cell onto each partial tray, which were then placed inside a walk-in growth chamber (C6 Control System with EcoSys Software; Environmental Growth Chambers, Chagrin Falls, OH) on 15 Feb. 2019. Transplants were acclimated for $48 \mathrm{~h}$ under a PPFD of $35 \pm 5 \mu \mathrm{mol} \cdot \mathrm{m}^{-2} \cdot \mathrm{s}^{-1}$ provided by broadband W LED fixtures (RAY66 PhysioSpec Indoor; Fluence Bioengineering, Austin, TX) used for $20 \mathrm{~h} \cdot \mathrm{d}^{-1}$ (0500 to 0100 $\mathrm{HR}$ ) and controlled by dimmers (Solunar, Fluence Bioengineering) connected to a backup battery (BE425M-LM; APC, West Kingston, RI). Average ambient temperature, relative humidity $(\mathrm{RH})$, and carbon dioxide $\left(\mathrm{CO}_{2}\right)$ concentration were set at constant $20^{\circ} \mathrm{C}$, $95 \%$, and $800 \mu \mathrm{mol} \cdot \mathrm{mol}^{-1}$, respectively.

In Expt. 2, TC 'Emerald' blueberries were received from the same transplant supplier (AgriStarts) on 16 June 2020. Industry standard, 128-cell propagation trays $(10 \mathrm{~mL}$ individual cell volume, Blackmore Co.) were cut into nine-cell $(3 \times 3)$ partial trays filled with a commercial peat-based substrate composed of (v/v) $79 \%$ to $87 \%$ peatmoss, $10 \%$ to $14 \%$ perlite, and $3 \%$ to $7 \%$ vermiculite (PRO-MIX BX Mycorrhizae; Premier Tech Horticulture, Quebec, Canada). On 22 June 2020, nine uniform transplants were planted one plant per cell onto each partial tray and acclimated following the same procedures previously described.

Treatments. In Expt. 1, transplants were moved inside two walk-in growth chambers (C6 Control System) on 17 Feb. 2019. Each chamber was equipped with two opposite shelving units that served as blocks, each with four treatment compartments $(61-\mathrm{cm}$ width $\times 183-\mathrm{cm}$ length $\times 47-\mathrm{cm}$ height $)$ that provided different PPFDs from broadband $\mathrm{W}$ LED fixtures (RAY66 PhysioSpec Indoor) to six partial trays per cultivar. The PPFD treatments were $35,70,105$, and $140 \pm 5$ $\mu \mathrm{mol} \cdot \mathrm{m}^{-2} \cdot \mathrm{s}^{-1}$ provided for $20 \mathrm{~h} \cdot \mathrm{d}^{-1}(0500$ to $0100 \mathrm{HR}$ ), which resulted in daily light integrals (DLIs) of $2.5,5.0,7.6$, or $10.1 \mathrm{~mol} \cdot \mathrm{m}^{-2} \cdot \mathrm{d}^{-1}$, respectively. Lamp output was controlled with dimmers (Solunar, Fluence Bioengineering) based on radiation maps generated using a spectroradiometer (SS-110; Apogee Instruments Inc., Logan, UT) placed at midcanopy height. A fifth treatment consisted of increasing the PPFD over time, which was achieved by moving six additional partial trays from treatment compartments providing 70 to $140 \mu \mathrm{mol} \cdot \mathrm{m}^{-2} \cdot \mathrm{s}^{-1}$ at the end of week 4 (INCR). In two additional treatments, four groups of three partial trays were placed on separate benches in either an RGH in Gainesville, FL, or a CGH in Apopka, FL (AgriStarts), both polycarbonate structures with computerized environmental control systems.

Similar to the setup previously described, each treatment in Expt. 2 was replicated in four individual treatment compartments (61$\mathrm{cm}$ width $\times 183-\mathrm{cm}$ length $\times 47-\mathrm{cm}$ height $)$ inside two walk-in growth chambers (C6 Control System), each with two opposite shelving units that served as blocks. Each compartment initially held six partial trays placed on 24 June 2020. The back and sides of all compartments were covered with a $0.3-\mathrm{mm}$ thick black and white polyethylene film to minimize radiation pollution $\left(\leq 1 \mu \mathrm{mol} \cdot \mathrm{m}^{-2} \cdot \mathrm{s}^{-1}\right)$ within the experimental area. The radiation-quality treatments were constant W, WR, or WFR (detailed in Tables 1 and 2). All treatments provided a PPFD of $70 \pm 2 \mu \mathrm{mol} \cdot \mathrm{m}^{-2} \cdot \mathrm{s}^{-1}$. Transplants under the WFR treatment also received $70 \mu \mathrm{mol} \cdot \mathrm{m}^{-2} \cdot \mathrm{s}^{-1}$ of $\mathrm{FR}$ radiation, which resulted in a total photon flux density $(\mathrm{PPFD}+\mathrm{FR})$ of $140 \pm 2 \mu \mathrm{mol} \cdot \mathrm{m}^{-2} \cdot \mathrm{s}^{-1}$. Treatments were delivered by two broadband W LED fixtures (RAY66 PhysioSpec Indoor, Fluence Bioengineering) without or with a single red or FR LED fixture (RAY66, Fluence Bioengineering) with peak wavelengths of 664 and $730 \mathrm{~nm}$, respectively, provided for $20 \mathrm{~h} \cdot \mathrm{d}^{-1}(0500$ to $0100 \mathrm{HR})$. At the end of week 4, three partial trays from WR and WFR were moved to additional treatment compartments with $\mathrm{W}\left(\mathrm{WR}_{\mathrm{W}}\right.$ or $\mathrm{WFR}_{\mathrm{W}}$, respectively) or from $\mathrm{W}$ to a research greenhouse $\left(\mathrm{W}_{\mathrm{GH}}\right)$, where they were grown for another 4 weeks to evaluate the effect of a spectral change over time. An additional treatment was included in which four groups of three partial trays were acclimated for 8 weeks in an RGH.

Environmental conditions and cultural practices during acclimation. In both experiments, the ambient setpoints for air temperature and $\mathrm{CO}_{2}$ concentration of the chambers were set at day/night $22 / 18^{\circ} \mathrm{C}$ and $800 \mu \mathrm{mol} \cdot \mathrm{mol}^{-1}$, respectively. The RH was maintained at $95 \%$ during the first 2 weeks using ultrasonic foggers (12 Disc Mist Maker; The House of Hydro, Ft.
Myers, FL) and progressively reduced until levels reached $70 \%$. Within each compartment, air temperature, $\mathrm{RH}$, and leaf temperature were monitored with temperature and RH probes (HMP60-L; Campbell Scientific, Logan, UT) and fixed-mounted infrared radiometers (SI-131-SS, Apogee Instruments) interfaced to a datalogger (CR1000, Campbell Scientific). Data were measured every $15 \mathrm{~s}$ and the average was logged every $10 \mathrm{~min}$. In each growth chamber, average $\mathrm{CO}_{2}$ concentration was logged every $15 \mathrm{~min}$ by a built-in datalogger (DL1 Datalogger; Environmental Growth Chambers). In addition, until the end of week 4 in Expt. 2, all partial trays were covered with clear plastic, vented humidity domes (54 $\mathrm{cm} \times 28 \mathrm{~cm} \times 15 \mathrm{~cm}$; Acro Dome, Acro Plastics, LTD, Edmonton, Alberta, Canada) to maximize RH during root formation. The average daily air temperature, leaf temperature, $\mathrm{RH}$, and $\mathrm{CO}_{2}$ concentration were (mean $\pm \mathrm{SD}$ ) $22.6 \pm 0.1^{\circ} \mathrm{C}, 23.7 \pm 0.4{ }^{\circ} \mathrm{C}$, $89.2 \% \pm 5.6 \%$, and $789 \pm 37 \mu \mathrm{mol} \cdot \mathrm{mol}^{-1}$, respectively, during Expt. 1, and $21.4 \pm$ $0.1^{\circ} \mathrm{C}, 21.8 \pm 0.2{ }^{\circ} \mathrm{C}, 94.1 \% \pm 2.0 \%$, and $839 \pm 97 \mu \mathrm{mol} \cdot \mathrm{mol}^{-1}$, respectively, during Expt. 2.

In both experiments, transplants acclimated indoors were initially sub-irrigated with tap water [electrical conductivity of $0.4 \mathrm{dS} \cdot \mathrm{m}^{-1}$, $\mathrm{pH}$ of 8.3 , and $40 \mathrm{mg} \cdot \mathrm{L}^{-1}$ of calcium carbonate $\left.\left(\mathrm{CaCO}_{3}\right)\right]$. Fertilizer application began at week 3 , once root growth was visible. A water-soluble fertilizer $(17 \mathrm{~N}-4 \mathrm{P}-17 \mathrm{~K}$; Blackmore Company, Belleville, MI) was used with each subirrigation event, providing (in $\mathrm{mg} \cdot \mathrm{L}^{-1}$ ) 19 ammonium $\left(\mathrm{NH}_{4}\right)-\mathrm{N}, 56$ nitrate $\left(\mathrm{NO}_{3}\right)-\mathrm{N}$, $10 \mathrm{P}, 62 \mathrm{~K}, 15 \mathrm{Ca}, 8 \mathrm{Mg}, 0.38 \mathrm{Fe}, 0.19 \mathrm{Mn}$, $0.19 \mathrm{Zn}, 0.04 \mathrm{Cu}, 0.08 \mathrm{~B}$, and $0.04 \mathrm{Mo}$.

Transplants acclimated in the research greenhouse (RGH and GH for Expts. 1 and 2, respectively) were shaded during the first 4 weeks of the experiments using fixed shade curtains (56\% shade; Solaro 5620 O-R-FR; Ludvig Svensson, Inc., Charlotte, NC). Aluminized $49 \%$ shade curtains (OLS 50, Ludvig Svensson, Inc.) controlled by an environmental control system (Gemlink; Hortimax, Rancho Santa Margarita, CA) were also retracted when the outdoor PPFD reached $750 \mu \mathrm{mol} \cdot \mathrm{m}^{-2} \cdot \mathrm{s}^{-1}$. Environmental conditions were monitored with a portable datalogger (HOBO MicroStation; Onset Computer Corporation, Bourne, MA)

Table 1. Spectral characteristics of sole-source lighting treatments used to evaluate indoor acclimation of blueberry transplants in Expts. 1 and 2.

\begin{tabular}{|c|c|c|c|c|c|c|c|c|}
\hline & $\begin{array}{c}\text { Blue } \\
(401-500 \mathrm{~nm})\end{array}$ & $\begin{array}{c}\text { Green } \\
(501-600 \mathrm{~nm})\end{array}$ & $\begin{array}{c}\text { Red } \\
(601-700 \mathrm{~nm})\end{array}$ & $\begin{array}{c}\text { Far-red } \\
(701-800 \mathrm{~nm})\end{array}$ & $\begin{array}{c}\text { TPFD }^{\mathrm{y}} \\
(401-800 \mathrm{~nm})\end{array}$ & $\begin{array}{c}\text { PPFD }^{\mathrm{x}} \\
(401-700 \mathrm{~nm})\end{array}$ & YPFD $^{w}$ & \\
\hline Treatment $^{\mathrm{z}}$ & \multicolumn{7}{|c|}{$\left(\mu \mathrm{mol} \cdot \mathrm{m}^{-2} \cdot \mathrm{s}^{-1}\right)$} & $\mathrm{R}: \mathrm{FR}^{\mathrm{v}}$ \\
\hline$\overline{\mathrm{W}}$ & $14(19 \%)^{\mathrm{u}}$ & $29(41 \%)$ & $28(39 \%)$ & $1(1 \%)$ & 72 & 71 & 62 & 12 \\
\hline WFR & $12(9 \%)$ & $27(19 \%)$ & $30(22 \%)$ & $71(50 \%)$ & 140 & 70 & 75 & 0.2 \\
\hline
\end{tabular}

${ }^{\mathrm{z}} \mathrm{W}=$ white; $\mathrm{R}=$ red; FR = far-red light-emitting diodes; all treatments evaluated in Expt. 1 used $\mathrm{W}$.

${ }^{\mathrm{y}}$ TPFD $=$ total photon flux density (photon flux integral between 401 and $800 \mathrm{~nm}$ ).

${ }^{x}$ PPFD $=$ photosynthetic photon flux density (photon flux integral between 401 and $700 \mathrm{~nm}$ ).

${ }^{\mathrm{w}} \mathrm{YPFD}=$ yield photon flux density, which is the product of TPFD and relative quantum efficiency, as calculated with a spectroradiometer (SS-110; Apogee Instruments Inc., Logan, UT).

${ }^{\mathrm{v}} \mathrm{R}: \mathrm{FR}=$ ratio of photon flux integral of R and FR radiation, as calculated with a spectroradiometer (SS-110, Apogee Instruments Inc.).

${ }^{\mathrm{u}}$ Numbers in parentheses represent the percentage of each waveband from TPFD. 
Table 2. Mean shrinkage, leaf number, and leaf area of 'Emerald' blueberry transplants acclimated for 8 weeks indoors under sole-source lighting or in a greenhouse in Expt. 2.

\begin{tabular}{|c|c|c|c|c|c|}
\hline Treatment code $\mathrm{e}^{\mathrm{z}}$ & Weeks 0 to 4 & Weeks 5 to 8 & Shrinkage $(\%)$ & Leaves (no.) & Leaf area $\left(\mathrm{cm}^{2}\right)$ \\
\hline$\overline{\mathrm{W}}$ & $\mathrm{W}$ & $\mathrm{W}$ & $1.4 \mathrm{c}^{\mathrm{y}}$ & $15.8 \mathrm{a}$ & $36.8 \mathrm{a}$ \\
\hline WR & $\mathrm{W}+\mathrm{R}$ & $\mathrm{W}+\mathrm{R}$ & $1.4 \mathrm{c}$ & $14.5 \mathrm{ab}$ & $31.8 \mathrm{ab}$ \\
\hline WFR & $\mathrm{W}+\mathrm{FR}$ & $\mathrm{W}+\mathrm{FR}$ & $1.4 \mathrm{c}$ & $15.4 \mathrm{ab}$ & $40.9 \mathrm{a}$ \\
\hline $\mathrm{GH}$ & $\mathrm{GH}$ & $\mathrm{GH}$ & $36.8 \mathrm{a}$ & $14.7 \mathrm{ab}$ & $17.1 \mathrm{~b}$ \\
\hline $\mathrm{W}_{\mathrm{GH}}$ & W & $\mathrm{GH}$ & $13.9 \mathrm{~b}$ & $13.4 \mathrm{~b}$ & $17.3 \mathrm{~b}$ \\
\hline $\mathrm{WR}_{\mathrm{W}}$ & $\mathrm{W}+\mathrm{R}$ & $\mathrm{W}$ & $1.4 \mathrm{c}$ & $15.9 \mathrm{a}$ & $36.7 \mathrm{a}$ \\
\hline $\mathrm{WFR}_{\mathrm{W}}$ & WFR & W & $4.2 \mathrm{c}$ & $15.3 \mathrm{ab}$ & $30.8 \mathrm{ab}$ \\
\hline
\end{tabular}

${ }^{\mathrm{z}} \mathrm{W}=$ white; $\mathrm{R}=$ red; FR $=$ far-red light-emitting diodes; $\mathrm{GH}=$ greenhouse. Treatment codes with a subscript indicate that transplants were moved to another environment at week 4 (represented by the subscript).

${ }^{\mathrm{y}}$ Means within column followed by the same letter are not different based on Tukey's honestly significant difference test at $P \leq 0.05$ (n $=4$ ).

and the average DLI, air temperature, and $\mathrm{RH}$ were $3.8 \pm 1.3 \mathrm{~mol} \cdot \mathrm{m}^{-2} \cdot \mathrm{d}^{-1}, 23.2 \pm 0.4^{\circ} \mathrm{C}$, and $81.5 \% \pm 9.0 \%$, respectively, during Expt. 1 and $7.4 \pm 1.5 \mathrm{~mol} \cdot \mathrm{m}^{-2} \cdot \mathrm{d}^{-1}, 27.4 \pm 1.6^{\circ} \mathrm{C}$, and $85.6 \% \pm 8.6 \%$, respectively, during Expt. 2 .

In both experiments, transplants in the research greenhouse (RGH and $\mathrm{GH}$ for Expts. 1 and 2, respectively) were irrigated using overhead mist with $69 \mu \mathrm{m}$-diameter emitters (Coolnet Pro Fogger, Netafim, Israel) spaced $91 \mathrm{~cm}$ apart. During the first 2 weeks, mist was provided for $10 \mathrm{~s}$ every 15 min or when the radiation level inside the greenhouse accumulated $100 \mathrm{mmol} \cdot \mathrm{m}^{-2}$ per mist cycle, and every $30 \mathrm{~min}$ at night. On weeks 3 to 4 , mist was provided for $7 \mathrm{~s}$ every $20 \mathrm{~min}$ or when the radiation level inside the greenhouse accumulated $120 \mathrm{mmol} \cdot \mathrm{m}^{-2}$ per mist cycle, and every $2 \mathrm{~h}$ at night. Mist frequency was further reduced from weeks 4 to 8 during the daytime to $7 \mathrm{~s}$ every hour or when the radiation level inside the greenhouse accumulated $120 \mathrm{mmol} \cdot \mathrm{m}^{-2}$, with no mist provided during the night period. The same fertilizer previously described was applied as a foliar spray once daily from week 3 onward.

In Expt. 1, transplants in the CGH were acclimated following standard commercial practices. Transplants were moved from the laboratory into the greenhouse immediately after planting into twelve 20 -cell $(4 \times 5)$ partial trays $(5 \mathrm{~mL}$ individual cell volume) arranged in four groups of three. Mist irrigation was provided for $4 \mathrm{~s}$ every $12 \mathrm{~min}$ throughout the experimental period and transplants were never fertilized. Environmental conditions were monitored with a portable datalogger (HOBO MicroStation) and the average daily DLI, air temperature, and RH during the experiment were $4.3 \pm 1.4$ $\mathrm{mol} \cdot \mathrm{m}^{-2} \cdot \mathrm{d}^{-1}, 22.8 \pm 1.9^{\circ} \mathrm{C}$, and $79.4 \% \pm$ $8.9 \%$, respectively.

Finishing culture and environment. In both experiments, after 8 weeks of treatment exposure, two randomly selected transplants from each partial tray were transplanted into 72-cell trays $(30.7 \mathrm{~mL}$ individual cell volume) filled with the same commercial substrate used during acclimation. Transplants were grown for 3 weeks in a computer-controlled greenhouse with polycarbonate glazing located in Gainesville, FL. The average DLI, air temperature, and RH were $13.5 \pm$ $6.3 \mathrm{~mol} \cdot \mathrm{m}^{-2} \cdot \mathrm{d}^{-1}, 23.7 \pm 0.7^{\circ} \mathrm{C}$, and $81.2 \% \pm$ $10.4 \%$, respectively, during Expt. 1, and $12.4 \pm 4.1 \mathrm{~mol} \cdot \mathrm{m}^{-2} \cdot \mathrm{d}^{-1}, 26.8 \pm 1.3^{\circ} \mathrm{C}$, and
$88.2 \% \pm 2.9 \%$, respectively, during Expt. 2 . Transplants were overhead fertigated as needed using the same fertilizer solution described previously.

Data collection and analyses. In both experiments, shrinkage was quantified as transplant loss percentage per partial tray at week 8. In Expt. 1, five randomly selected transplants per partial tray were destructively harvested at weeks 4 and 8 . Stem length was measured with a ruler from the base of the substrate surface to the top of the transplant canopy. Shoot fresh mass (FM) was measured at harvest, and shoots were oven-dried to a constant mass at $70^{\circ} \mathrm{C}$ for shoot DM determination. After roots were washed from the substrate, they were separated and spread on a $10 \mathrm{~cm} \times 15 \mathrm{~cm}$ polycarbonate container filled with a thin layer of water and laid on a horizontal plane to acquire images of root morphology with a scanner (Perfection 4990 Photo; Epson, Suwa, Japan). Total root length and root area were calculated from scanned images using WinRHIZO (Regent Instrument Inc., Quebec, Canada). Immediately after scanning, roots were oven-dried to a constant mass at $70^{\circ} \mathrm{C}$ for $\mathrm{DM}$ determination.

In Expt. 2, three randomly selected transplants per partial tray were destructively harvested from the four initial treatments (W, WR, WFR, and GH) at week 4. Data collected included stem length, shoot and root DM, length of the longest root (measured with a ruler), and rooting quality based on a subjective scale from 1 to 5 , where $1=$ no or few roots, not transplantable, $2=$ lopsided and/or weakly developed root system, $3=$ moderately developed root system, $4=$ welldeveloped root system, and $5=$ extensive root system distributed around the tray cell. At week 8, stem length and leaf number per transplant $(>1 \mathrm{~cm})$ were measured from all remaining transplants in the seven final treatments. Leaf area was subsequently measured from up to three randomly selected transplants per partial tray (depending on shrinkage) using a leaf area meter (LI-3100C; LICOR Biosciences, Lincoln, NE). Shoot and root $\mathrm{DM}$, length of the longest root, and rooting quality were measured from those same transplants following the procedures described previously. In both experiments, stem length, number of branches, and shoot and root DM were measured at week 11 from all transplants acclimated in the greenhouse during the finish stage.

One transplant per partial tray was used to quantify chlorophyll and anthocyanin concentration in Expt. 2 using 3.1- $\mathrm{cm}^{2}$ disks collected at week 8 from middle-canopy leaves. Tissue samples were flash-frozen in liquid nitrogen and immediately placed in a freezer at $-80^{\circ} \mathrm{C}$ until the point of extraction. Chlorophyll content was measured following the dimethyl sulfoxide (DMSO) extraction method described in Richardson et al. (2002). Glass vials were wrapped in aluminum foil to protect samples from radiation exposure. The vials contained $7 \mathrm{~mL}$ DMSO and were preheated in a $65^{\circ} \mathrm{C}$ water bath. Samples were placed inside vials with DMSO and extracted for $30 \mathrm{~min}$ in the dark, after which the extracted liquid was brought to a volume of $10 \mathrm{~mL}$ with DMSO, and $2.5 \mathrm{~mL}$ of each extract was then transferred to a disposable polystyrene cuvette. Pure DMSO was used as the blank. The absorbance of both blank and samples were measured with a spectrophotometer (SpectraMax Plus 384; Molecular Devices, Sunnyvale, CA) at 480, 649, and $665 \mathrm{~nm}$. Chlorophyll was calculated using the equations from Wellburn (1994). Anthocyanins were measured using the methanol extraction method described in Gould et al. (2000). Samples were agitated gently in the dark for $24 \mathrm{~h}$ at $4{ }^{\circ} \mathrm{C}$ in $1 \mathrm{~mL}$ of $3 \mathrm{M}$ hydrogen chloride, water, and methanol $(1: 3: 16 \mathrm{v} / \mathrm{v})$. Samples were then placed in a centrifuge for $15 \mathrm{~min}$. The absorbance of the extracts was measured with a spectrophotometer at 530 (A530) and 653 (A653) nm, with methanol used as the blank solution. Anthocyanin concentration was calculated as A530 - $(0.24 \times$ A653).

Each experiment was performed once and had four treatment replications. In both experiments, transplants acclimated indoors were arranged in a randomized complete block design in which each shelf within a growth chamber was regarded as a block with one treatment compartment as a replication. Greenhouse-acclimated transplants were arranged in a completely randomized design with four replicate group sections. In Expt. 1, data from six or three partial trays in the indoor or greenhouse treatments, respectively, were averaged and treated as a single data point per replication for each cultivar. Because the cultivar $\times$ treatment interaction was not significant $(P>0.05)$, data were 
pooled for the main effect treatment means $(\mathrm{n}=8)$. A linear regression analysis was then conducted to compare growth trends from transplants acclimated under all constant PPFD treatments $(35,70,105$, and $140 \mu \mathrm{mol} \cdot \mathrm{m}^{-2} \cdot \mathrm{s}^{-1}$ ) using JMP (Version 15; SAS Institute Inc., Cary, NC). To identify differences among all treatments (including INCR, RGH, and $\mathrm{CGH}$ ), pairwise comparisons for the main effect treatment means were also completed using Tukey's honestly significant difference (HSD) test $(P \leq 0.05)$. During the finish stage, transplants were arranged in a completely randomized design. Regression analyses and treatment mean comparison were completed following the same procedures previously described. In Expt. 2, data collected from the same partial tray were averaged and treated as a single data point per replication $(n=4)$. Pairwise comparisons for the main effect treatment means were completed using Tukey's HSD test $(P \leq 0.05)$.

\section{Results}

Expt. 1. Although shrinkage was unaffected by PPFD, transplants acclimated indoors had a significantly lower shrinkage percentage $(<4 \%)$ than those in the greenhouse, where at week 8 , shrinkage of transplants acclimated in RGH or CGH was $15 \%$ or $17 \%$, respectively (Fig. 1A). There were no treatment differences in stem length at week 4 (Fig. 1B); however, there was a negative linear relationship between PPFD and stem length at week 8 . Transplants acclimated under $105 \mu \mathrm{mol} \cdot \mathrm{m}^{-2} \cdot \mathrm{s}^{-1}$, INCR, or those acclimated in $\mathrm{RGH}$ or $\mathrm{CGH}$ had $18 \%, 15 \%$, $17 \%$, or $17 \%$ shorter stems, respectively, than those acclimated under a PPFD of $35 \mu \mathrm{mol} \cdot \mathrm{m}^{-2} \cdot \mathrm{s}^{-1}$. Similarly, transplants acclimated under PPFDs of 70 or $140 \mu \mathrm{mol} \cdot \mathrm{m}^{-2} \cdot \mathrm{s}^{-1}$, as well as those under INCR, had shorter stems than those acclimated in CGH at week 8. In both harvest weeks, shoot DM increased in response to PPFD (Fig. 1C). At week 4, transplants acclimated under PPFDs of 105 or $140 \mu \mathrm{mol} \cdot \mathrm{m}^{-2} \cdot \mathrm{s}^{-1}$ had a similar shoot DM, which was $47 \%$ to $282 \%$ higher than that in any other treatment. At week 8, transplants acclimated indoors under a PPFD of $35 \mu \mathrm{mol}$ $\mathrm{m}^{-2} \cdot \mathrm{s}^{-1}$ or in CGH had lower shoot DM than those in all other treatments, and this shoot growth was also lower than that at week 4 under 105 or $140 \mu \mathrm{mol} \cdot \mathrm{m}^{-2} \cdot \mathrm{s}^{-1}$.
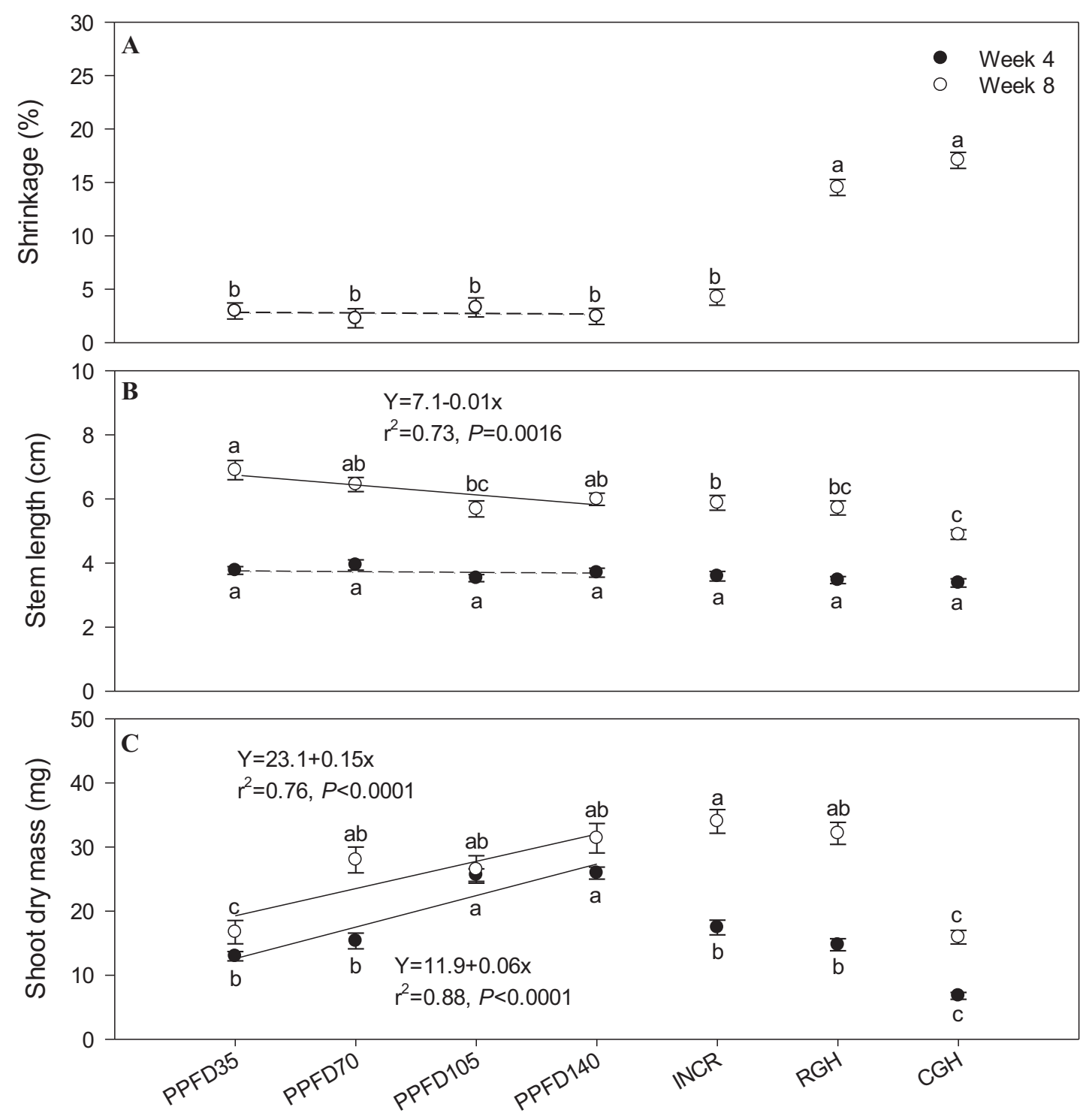

Treatment

Fig. 1. Shrinkage and shoot growth of blueberry transplants acclimated indoors under five photosynthetic photon flux density (PPFD) treatments (where INCR = plants moved to an increasing PPFD from 70 to $140 \mu \mathrm{mol} \cdot \mathrm{m}^{-2} \cdot \mathrm{s}^{-1}$ at week 4$)$, or in a research (RGH) or commercial (CGH) greenhouse in Expt. 1. Equations, correlation coefficients $\left(r^{2}\right)$, and $P$ values are presented when the linear response to increasing PPFD was statistically significant (solid line) but not when not significant (dashed line). Means followed by the same letter are not different based on Tukey's honestly significant difference test $(\alpha=0.05)$. Data points represent the treatment mean $\pm \operatorname{SE}(n=8)$. 

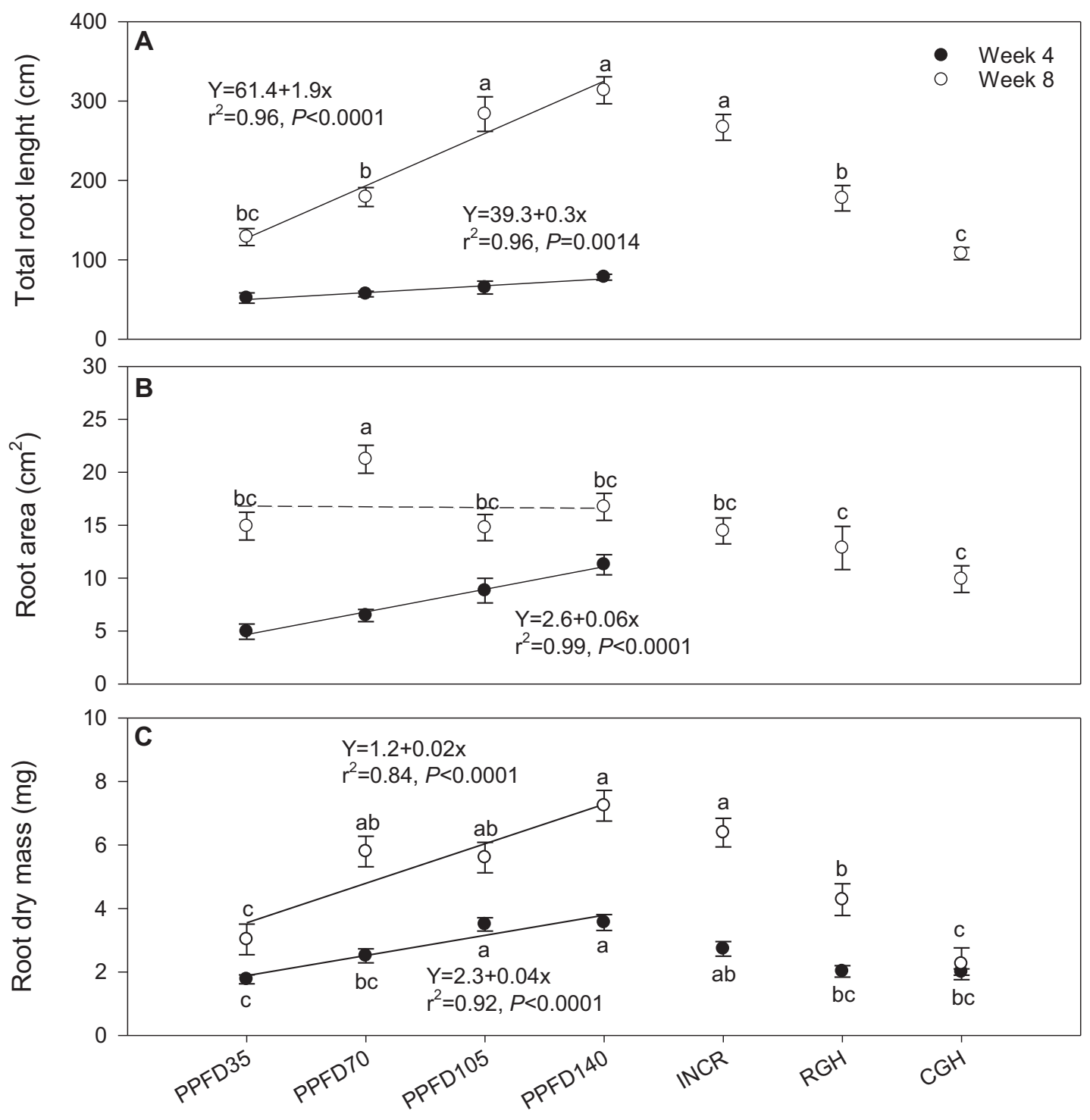

Treatment

Fig. 2. Root growth of blueberry transplants acclimated indoors under five photosynthetic photon flux density (PPFD) treatments (where INCR $=$ plants moved to an increasing PPFD from 70 to $140 \mu \mathrm{mol} \cdot \mathrm{m}^{-2} \cdot \mathrm{s}^{-1}$ at week 4), or in a research (RGH) or commercial (CGH) greenhouse in Expt. 1. Equations, correlation coefficients $\left(r^{2}\right)$, and $P$ values are presented when the linear response to increasing PPFD was statistically significant (solid line) but not when not significant (dashed line). Within week, means followed by the same letter are not different based on Tukey's honestly significant difference test $(\alpha=$ $0.05)$. Data points represent the treatment mean \pm SE $(n=8)$.

Total root length increased with increasing PPFD in both harvest weeks (Fig. 2A). However, the positive effects of higher PPFDs were more noticeable at week 8 , when transplants acclimated under INCR or under PPFDs of 105 or $140 \mu \mathrm{mol} \cdot \mathrm{m}^{-2} \cdot \mathrm{s}^{-1}$ produced the largest roots. In contrast, transplants acclimated under a PPFD of $35 \mu \mathrm{mol} \cdot \mathrm{m}^{-2} \cdot \mathrm{s}^{-1}$ or in CGH produced the shortest roots. There was a positive linear response to PPFD for root area at week 4 (Fig. 2B); however, the response to PPFD was not significant for root area at week 8 , as transplants acclimated under a PPFD of $70 \mu \mathrm{mol} \cdot \mathrm{m}^{-2} \cdot \mathrm{s}^{-1}$ produced from $27 \%$ to $114 \%$ more root area than those in any other treatment. Root DM also had a positive linear response to PPFD in both harvest weeks (Fig. 2C), which suggests that the response to root area at week 8 under
$70 \mu \mathrm{mol} \cdot \mathrm{m}^{-2} \cdot \mathrm{s}^{-1}$ could be attributed to human error. At week 4, transplants acclimated under PPFDs of 105 or $140 \mu \mathrm{mol} \cdot \mathrm{m}^{-2} \cdot \mathrm{s}^{-1}$ produced from $39 \%$ to $102 \%$ more root DM than those under 35 or $70 \mu \mathrm{mol} \cdot \mathrm{m}^{-2} \cdot \mathrm{s}^{-1}$, or those acclimated in $\mathrm{RGH}$ or $\mathrm{CGH}$, but their root $\mathrm{DM}$ was similar to that produced under INCR. At week 8 , root $\mathrm{DM}$ was lowest in transplants acclimated under a PPFD of $35 \mu \mathrm{mol} \cdot \mathrm{m}^{-2} \cdot \mathrm{s}^{-1}$ or in CGH. Similar to results for shoot DM, transplants acclimated under 105 or $140 \mu \mathrm{mol} \cdot \mathrm{m}^{-2} \cdot \mathrm{s}^{-1}$ had already produced more root DM at week 4 than that produced under $35 \mu \mathrm{mol} \cdot \mathrm{m}^{-2} \cdot \mathrm{s}^{-1}$ or in CGH at week 8.

The linear response to PPFD was not significant during the finish stage for stem length, shoot DM, and root DM (Fig. 3A-C); however, stems of transplants acclimated under 70 $\mu \mathrm{mol} \cdot \mathrm{m}^{-2} \cdot \mathrm{s}^{-1}$ were $9 \%, 13 \%, 35 \%$, or $40 \%$ longer than those under $35 \mu \mathrm{mol} \cdot \mathrm{m}^{-2} \cdot \mathrm{s}^{-1}$, INCR, RGH, or CGH, respectively. In addition, stems of greenhouse-acclimated transplants were consistently shorter than those acclimated indoors. There was also a slight decrease in the number of branches of transplants acclimated in CGH compared with those indoors. Further, transplants acclimated under a PPFD of $35 \mu \mathrm{mol} \cdot \mathrm{m}^{-2} \cdot \mathrm{s}^{-1}$ produced up to $41 \%$ more branches than those in either greenhouse environment (Fig. 3D). Regardless of PPFD, transplants acclimated indoors produced more root and shoot biomass during the finish stage than those acclimated in RGH or CGH.

Expt. 2. At week 8, shrinkage of transplants acclimated indoors ranged from $1 \%$ to $4 \%$ (Table 2). In contrast, shrinkage of transplants acclimated in $\mathrm{GH}$ was $37 \%$, which was higher than that of those moved from $\mathrm{W}$ 

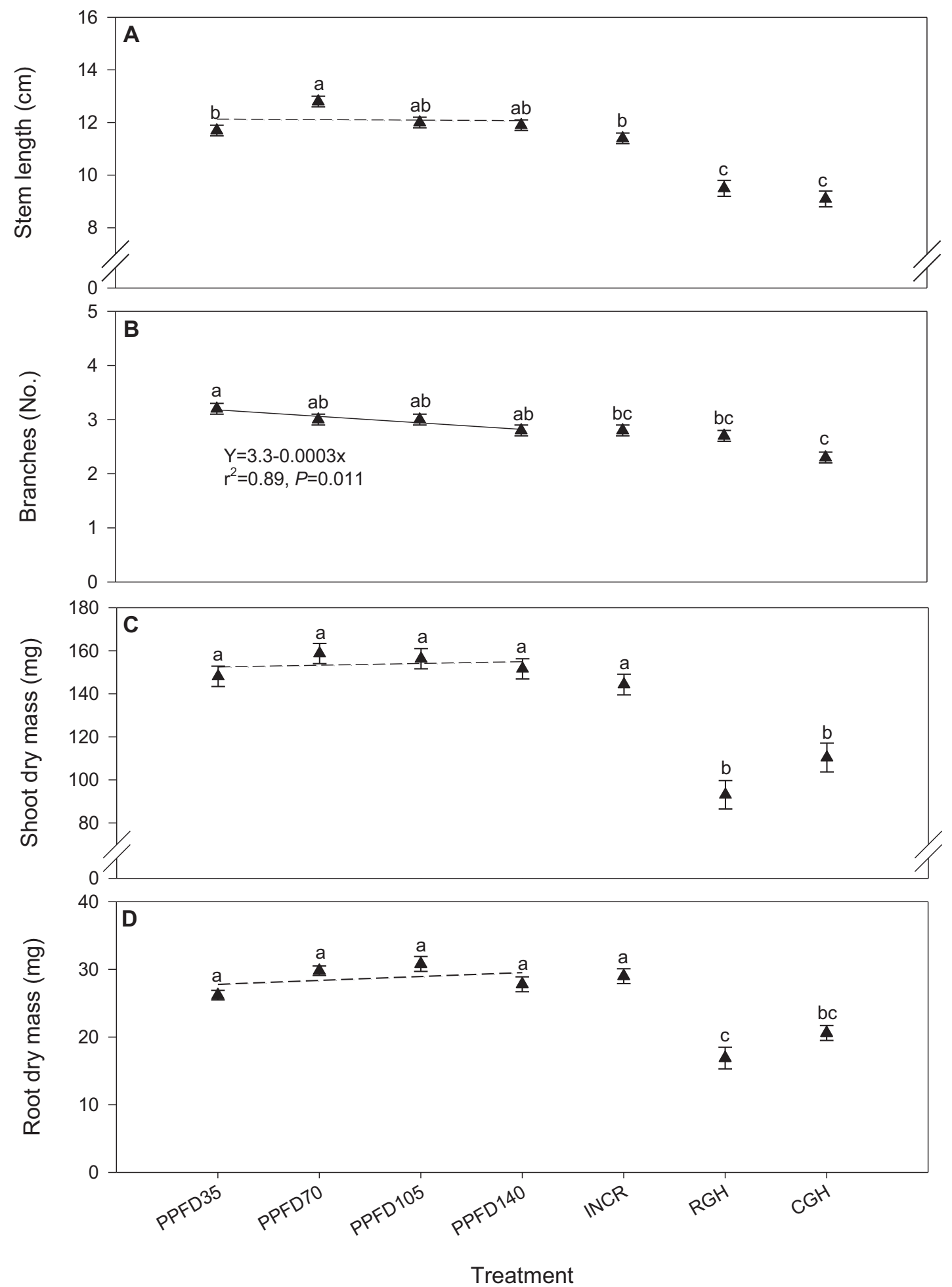

Fig. 3. Growth effects after finishing of blueberry transplants acclimated indoors under five photosynthetic photon flux density (PPFD) treatments (where INCR = plants moved to an increasing PPFD from 70 to $140 \mu \mathrm{mol} \cdot \mathrm{m}^{-2} \cdot \mathrm{s}^{-1}$ at week 4), or in a research (RGH) or commercial (CGH) greenhouse in Expt. 1. Equations, correlation coefficients $\left(r^{2}\right)$, and $P$ values are presented when the linear response to increasing PPFD was statistically significant (solid line) but not when not significant (dashed line). Means followed by the same letter are not different based on Tukey's honestly significant difference test $(\alpha=0.05)$. Data points represent the treatment mean $\pm \operatorname{SE}(n=8)$.

to the $\mathrm{GH}\left(\mathrm{W}_{\mathrm{GH}}\right)$, which had a shrinkage percentage of $14 \%$. At week 4 , transplants acclimated continuously under FR (WFR) had $10 \%$ or $8 \%$ longer stems than those under $\mathrm{W}$ or in $\mathrm{GH}$, respectively, but stem length was similar between transplants acclimated under WFR and WR (Table 3). At week 8, stems of transplants acclimated under WFR were longer than those under $\mathrm{WFR}_{\mathrm{W}}, \mathrm{W}_{\mathrm{GH}}$, or in $\mathrm{GH}$.

At week 4, transplants acclimated in $\mathrm{GH}$ produced the lowest shoot DM, and values were similar among all indoor-acclimated transplants (Table 3). At week 8, transplants acclimated under WFR and $\mathrm{WR}_{\mathrm{W}}$ had $87 \%$ higher shoot DM than those under $\mathrm{W}_{\mathrm{GH}}$. At week 4 , transplants under WFR had $163 \%$ or $85 \%$ higher root DM than those in $\mathrm{GH}$ or under $\mathrm{W}_{\mathrm{GH}}$, respectively, but root $\mathrm{DM}$ was similar between WFR and WR. Similarly, transplants under WFR had more than twice the root $\mathrm{DM}$ of those in $\mathrm{GH}$ or under $\mathrm{W}_{\mathrm{GH}}$ 


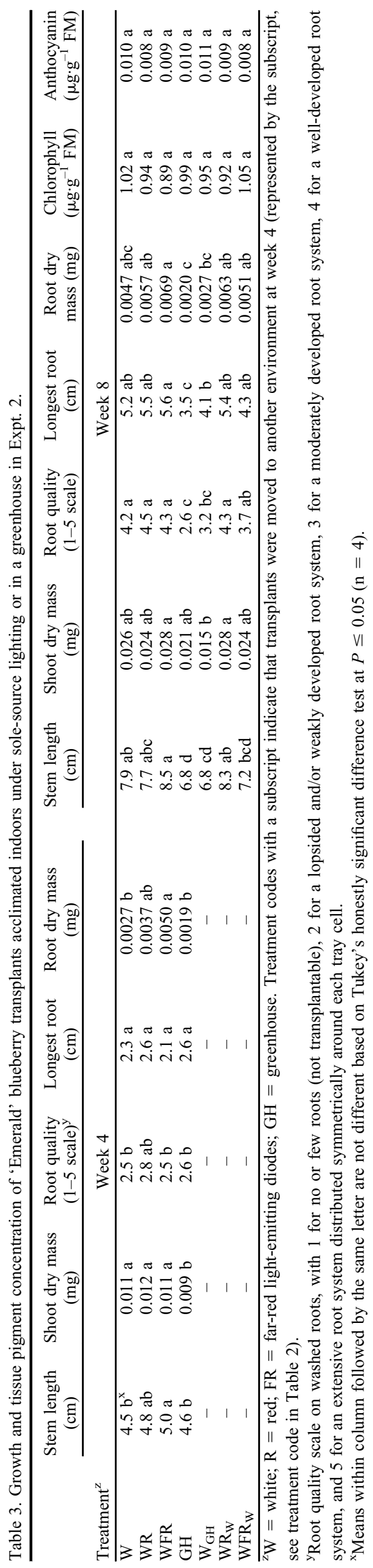

at week 8 , but means were similar among all radiation-quality treatments indoors. No differences were observed for root rating at week 4, but rooting of transplants acclimated indoors was generally rated higher than that of those in GH or under $\mathrm{W}_{\mathrm{GH}}$ at week 8. Similarly, transplants under WFR ultimately produced longer roots than those in $\mathrm{GH}$ or under $\mathrm{W}_{\mathrm{GH}}$, but there were no differences in root length among transplants acclimated indoors under the different radiation-quality treatments.

At week 8 , the total number of leaves per transplant was greater for plants acclimated under $\mathrm{W}$ or $\mathrm{WR}_{\mathrm{W}}$ compared with $\mathrm{W}_{\mathrm{GH}}$ (Table 2). The total leaf area measured at week 8 from transplants acclimated under $\mathrm{W}$, $\mathrm{WFR}$, and $\mathrm{WR}_{\mathrm{W}}$ was more than double of that produced in $\mathrm{GH}\left(17.1 \mathrm{~cm}^{2}\right)$ or under $\mathrm{W}_{\mathrm{GH}}\left(17.3 \mathrm{~cm}^{2}\right)$, but similar to that under $\mathrm{WR}$ and $\mathrm{WFR}_{\mathrm{W}}$. Although visually, plants under WFR, $\mathrm{GH}$, or $\mathrm{W}_{\mathrm{GH}}$ were green with less reddening than those from all other treatments (Fig. 4), leaf chlorophyll and anthocyanin concentration were similar among treatments, averaging 0.97 and $0.009 \mu \mathrm{g} \cdot \mathrm{g}^{-1}$ FM, respectively (Table 3).

During the finish stage, transplants acclimated in $\mathrm{GH}$ had $19 \%, 20 \%$, and $21 \%$ shorter stems than those under $\mathrm{W}, \mathrm{WFR}$, and $\mathrm{WR}_{\mathrm{W}}$, respectively (Table 4). Transplants acclimated under WFR or $\mathrm{WR}_{\mathrm{W}}$ produced more than twice the shoot DM than those in GH or under $\mathrm{W}_{\mathrm{GH}}$. Similarly, the root $\mathrm{DM}$ of transplants acclimated under WFR was $77 \%$ and $129 \%$ higher than that produced from transplants acclimated in $\mathrm{GH}$ or under $\mathrm{W}_{\mathrm{GH}}$. There were no other treatment effects in shoot and root $\mathrm{DM}$, and no significant differences were measured for the number of branches produced during the finish stage.

\section{Discussion}

Radiation effects on shrinkage. Our results from Expt. 1 showed that shrinkage was unaffected by PPFDs ranging from 35 to $140 \mu \mathrm{mol} \cdot \mathrm{m}^{-2} \cdot \mathrm{s}^{-1}$ (Fig. 1A). Furthermore, all indoor-acclimated transplants had significantly lower shrinkage percentages $(\leq 4 \%)$ than those acclimated in the greenhouse ( $\geq 15 \%)$, which were exposed to an average daily maximum PPFD of $230 \pm 71$ or $253 \pm 62 \mu \mathrm{mol} \cdot \mathrm{m}^{-2} \cdot \mathrm{s}^{-1}$ in the RGH or $\mathrm{CGH}$, respectively. Similar to our findings, Isutsa et al. (1994) reported $>97 \%$ survival of blueberry transplants acclimated indoors under PPFDs of 30,50 , or $100 \mu \mathrm{mol} \cdot \mathrm{m}^{-2} \cdot \mathrm{s}^{-1}$ provided by cool-white fluorescent lamps, but no comparison was made with $\mathrm{GH}$ propagation.

In Expt. 2, GH propagation also resulted in a larger shrinkage percentage $(\approx 37 \%)$ compared with indoor acclimation $(\leq 4 \%)$ (Table 2). Similarly, indoor acclimation under W with a transition to the GH after week 4 $\left(\mathrm{W}_{\mathrm{GH}}\right)$ had a shrinkage percentage of $14 \%$, suggesting that transplants would have benefited from additional acclimation time indoors. Although our findings do not show differences in shrinkage in response to radiation quality, Davis (2016) found that survival of silverberry (Elaeagnus sp.), photinia

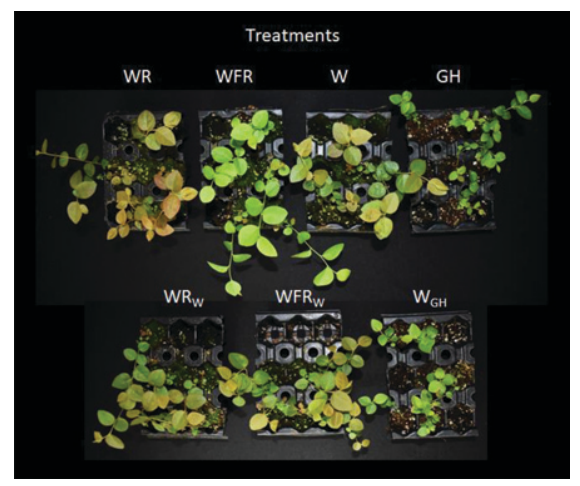

Fig. 4. Representative 'Emerald' blueberry transplants after 8 weeks of acclimation under light-emitting diode lamps providing white (W) without or with red (R) or far-red (FR) radiation, or in a greenhouse (GH) in Expt. 2.

(Photinia sp.), and rhododendron (Rhododendron sp.) cuttings decreased with the addition of blue radiation. Similar findings were reported by Navidad (2015) when comparing survival of subalpine fir (Abies lasiocarpa) and Norway spruce (Picea abies) cuttings propagated under broadband radiation without or with $75 \mu \mathrm{mol} \cdot \mathrm{m}^{-2} \cdot \mathrm{s}^{-1}$ from blue LEDs. Findings from both studies suggest that radiation quality from sole-source lighting can affect cutting shrinkage, most likely through an indirect effect on cutting dehydration.

Ex vitro acclimation is a critical phase that affects successful establishment and growth of TC transplants. During in vitro growth, TC transplants are typically exposed to low PPFDs ranging from 50 to $100 \mu \mathrm{mol} \cdot \mathrm{m}^{-2} \cdot \mathrm{s}^{-1}$ (Phillips and Garda, 2019), although PPFDs below $50 \mu \mathrm{mol} \cdot \mathrm{m}^{-2} \cdot \mathrm{s}^{-1}$ are not uncommon (Kumar and Rao, 2012). Low PPFDs tend to also be used during ex vitro acclimation to minimize shrinkage caused by photooxidative stress and dehydration, which often limit growth and development of TC transplants (Chandra et al., 2010; Gago et al., 2014; Pospísilová et al., 1999). That is because several anatomical, morphological, and physiological characteristics of in vitro growth (e.g., reduced epicuticular waxes, malfunctional stomata, and low levels of chlorophyll) limit photosynthetic capacity and water-loss regulation during the initial phases of ex vitro acclimation (Gago et al., 2014; Sáez et al., 2013). Therefore, it is generally recommended to progressively change environmental conditions such as PPFD and humidity during acclimation to reduce shrinkage or minimize growth delays of TC transplants (Chandra et al., 2010; Pospíšilová et al., 1999; Vieira et al., 2019; Zobayed, 2020). In commercial greenhouses, this is typically achieved by controlling shade curtains, supplemental lighting, and mist irrigation, among others. However, these systems have various limitations that often lead to cutting dehydration, which as shown in this study, can affect shrinkage during acclimation of TC transplants in greenhouses.

As highlighted by our findings, indoor acclimation using PPFDs and radiation 
Table 4. Growth effects after finishing 'Emerald' blueberry transplants acclimated indoors under sole-source lighting or in a greenhouse in Expt. 2.

\begin{tabular}{lcccc} 
Treatment & Stem length $(\mathrm{cm})$ & Branches (no.) & Shoot dry mass (mg) & Root dry mass (mg) \\
\hline $\mathrm{W}$ & $11.0 \mathrm{a}$ & $2.2 \mathrm{a}$ & $0.136 \mathrm{ab}$ & $0.027 \mathrm{ab}$ \\
$\mathrm{WR}$ & $10.7 \mathrm{ab}$ & $2.3 \mathrm{a}$ & $0.138 \mathrm{ab}$ & $0.160 \mathrm{a}$ \\
$\mathrm{WFR}$ & $11.1 \mathrm{a}$ & $2.5 \mathrm{a}$ & $0.072 \mathrm{~b}$ & $0.032 \mathrm{a}$ \\
$\mathrm{GH}$ & $8.9 \mathrm{~b}$ & $1.9 \mathrm{a}$ & $0.066 \mathrm{~b}$ & $0.018 \mathrm{~b}$ \\
$\mathrm{~W}_{\mathrm{GH}}$ & $9.2 \mathrm{ab}$ & $1.8 \mathrm{a}$ & $0.155 \mathrm{a}$ & $0.014 \mathrm{~b}$ \\
$\mathrm{WR}_{\mathrm{W}}$ & $11.3 \mathrm{a}$ & $2.3 \mathrm{a}$ & $0.112 \mathrm{ab}$ & $0.029 \mathrm{ab}$ \\
WFR $_{\mathrm{W}}$ & $10.1 \mathrm{ab}$ & $2.3 \mathrm{a}$ & $0.027 \mathrm{ab}$ \\
\hline
\end{tabular}

$\overline{\mathrm{z}} \mathrm{W}=$ white; $\mathrm{R}=$ red; FR $=$ far-red light-emitting diodes; $\mathrm{GH}=$ greenhouse. Treatment codes with a subscript indicate that transplants were moved to another environment at week 4, represented by the subscript (see Table 2).

${ }^{\mathrm{y}}$ Means within column followed by the same letter are not different based on Tukey's honestly significant difference test at $P \leq 0.05$ (n $=4$ ).

qualities like those used in our studies can maintain a low shrinkage percentage compared with GH propagation (Table 2, Fig. 1A). Although controlled environments offer opportunities to control environmental conditions in ways that can help minimize dehydration ex vitro, further studies are needed to better understand rate-limiting steps during indoor propagation. For example, elucidating how different PPFDs from sole-source lighting affect leaf-energy dynamics and vapor pressure deficit could help identify optimal control strategies that can minimize dehydration and maximize rate of adventitious rooting. In addition, careful quantification of the effects that radiation quality has on transpiration and water loss could prove to be beneficial when selecting LED fixtures for indoor acclimation.

Radiation quantity effects on growth. It is widely known that low PPFDs cause stem elongation as a shade-avoidance response in plants (Franklin and Whitelam, 2005). Accordingly, others have reported elongated stems of transplant grown under low compared with high PPFDs (Hernández and Kubota, 2014; Lopez and Runkle, 2008; Park et al., 2011; Pramuk and Runkle, 2005; Torres and Lopez, 2011), which correspond with our finding for stem length at week 8 (Fig. 1B). A plausible explanation for the lack of treatment differences in stem length at week 4 could be related to the fact that active shoot growth was most likely delayed at the expense of root formation and growth during the first few weeks of acclimation. This delay is not uncommon, as TC transplants must transition from heterotrophic to autotrophic conditions before resuming active plant growth (Pospíśilová et al., 1999; Van Huylenbroeck and Riek, 1995).

In both harvest weeks, higher PPFDs during indoor acclimation linearly increased shoot and root DM of blueberry transplants (Figs. 1C and 2C). This corresponds with the findings of others who have reported a general increase in biomass production of transplants with higher (but not saturating) PPFDs (Currey et al., 2012; Hernández and Kubota, 2014; Isutsa et al., 1994; Loach and Gay, 1979; Lopez and Runkle, 2008; Owen and Lopez, 2018; Pramuk and Runkle, 2005; Tombesi et al., 2015; Torres and Lopez, 2011). Numerous studies have shown that for seedlings, and to an extent for unrooted cuttings, higher DLIs typically provided with higher PPFDs, promote root initiation and formation, and shoot and root growth (Faust et al., 2017; Randall and Lopez, 2014). These enhancements in growth and development in response to higher DLIs are often associated with an increase in carbohydrate availability by the synthesis of photoassimilates (Rapaka et al., 2005). However, as indicated in some of the studies highlighted previously, transplants have maximum PPFD thresholds where processes can be inhibited. These thresholds are typically lower for TC transplants than for seedlings and unrooted cuttings. For example, the recommended PPFDs for the initial stages of propagation range from $\approx 100$ to $250 \mu \mathrm{mol} \cdot \mathrm{m}^{-2} \cdot \mathrm{s}^{-1}$ for seedlings (He, 2020; Randall and Lopez, 2014) and 120 to $200 \mu \mathrm{mol} \cdot \mathrm{m}^{-2} \cdot \mathrm{s}^{-1}$ for unrooted cuttings (Faust et al., 2017). In contrast, PPFDs $>100 \mu \mathrm{mol} \cdot \mathrm{m}^{-2} \cdot \mathrm{s}^{-1}$ are commonly considered stressful when TC transplants start to become photoautotrophic ex vitro. A potential alternative to increase growth of TC transplants using higher DLIs is to extend the photoperiod, provided that long days do not affect subsequent growth and development.

Except for shoot DM at week 4, transplants acclimated under PPFDs of 105 or 140 $\mu \mathrm{mol} \cdot \mathrm{m}^{-2} \cdot \mathrm{s}^{-1}$ produced similar shoot and root growth to those acclimated under INCR (Figs. 1 and 2). In addition, considering that PPFD minimally affected subsequent transplant growth at the finish stage (Fig. 3), initially acclimating TC transplants under $70 \mu \mathrm{mol} \cdot \mathrm{m}^{-2} \cdot \mathrm{s}^{-1}$ and subsequently providing higher PPFDs could be used as a strategy to reduce energy costs during indoor propagation, as the energy cost from sole-source lighting is expected to be the highest operating cost (Fisher et al., 2020). Nevertheless, only transplants acclimated under 105 or $140 \mu \mathrm{mol} \cdot \mathrm{m}^{-2} \cdot \mathrm{s}^{-1}$ produced more shoot and root $\mathrm{DM}$ than those in $\mathrm{CGH}$ at week 4 , illustrating the potential to reduce the propagation cycle by constantly providing higher PPFDs during indoor acclimation.

In general, growth responses to increasing PPFD during indoor acclimation were linear, suggesting that higher PPFDs could further increase subsequent growth of blueberry transplants (Figs. 1 and 2). However, further studies are needed to identify the PPFD threshold that will maximize growth without inducing undesirable stress responses, which could include the production of reactive oxygen species in chloroplasts and the accumulation of antioxidant enzymes, among others (Van Huylenbroeck et al., 2000; Vieira et al., 2019).
Accordingly, although not measured in Expt. 1, we found that plants acclimated under higher PPFDs showed a red leaf pigmentation (Fig. 5). Isutsa et al. (1994) also reported a "red discoloration" in the leaves of TC blueberry transplants acclimated under 100 $\mu \mathrm{mol} \cdot \mathrm{m}^{-2} \cdot \mathrm{s}^{-1}$ compared with those under 30 or $50 \mu \mathrm{mol} \cdot \mathrm{m}^{-2} \cdot \mathrm{s}^{-1}$. As described by others, red photoprotective pigments like anthocyanins tend to increase in response to high PPFD to help reduce excess radiation from reaching chloroplasts in leaves (Steyn et al., 2002; Trojak and Skowron, 2017). Interestingly, this red pigmentation was not visible at the end of the finish stage (data not shown). It is unclear if the changes in pigmentation indoors limited growth in response to higher PPFDs. However, studies have shown that plant growth and the accumulation of photoprotective pigments like anthocyanins are competing processes, and thus, the increase of one may result in a decrease of the other (Boldt et al., 2014).

Radiation-quality effects on growth. The differences among radiation-quality treatments were small and spectral changes over time $\left(\mathrm{WR}_{\mathrm{W}}\right.$ or $\left.\mathrm{WFR}_{\mathrm{W}}\right)$ did not provide significant growth advantages compared with constant radiation-quality treatments (W, WR, or WFR) (Tables 2 and 3). However, growth of indooracclimated transplants was generally greater

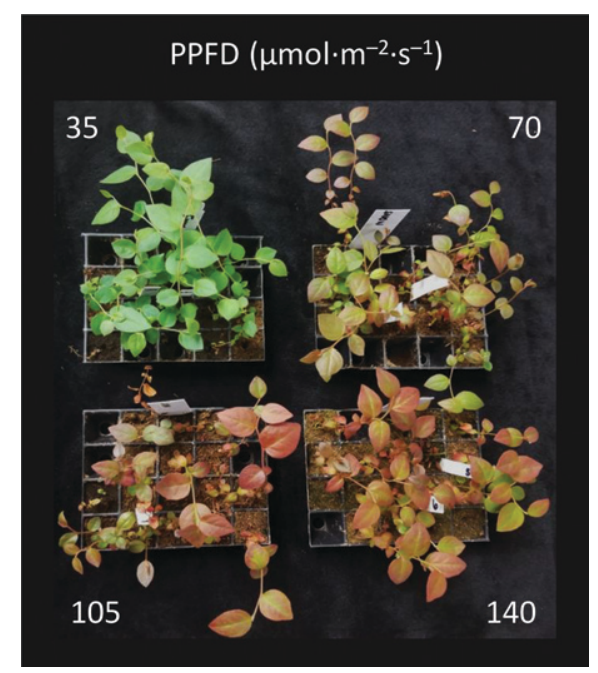

Fig. 5. Representative 'Snowchaser' blueberry transplants after 8 weeks of indoor acclimation under different photosynthetic photon flux densities (PPFD) in Expt. 1. 
than that in $\mathrm{GH}$ or under $\mathrm{W}_{\mathrm{GH}}$. Although transplants acclimated under $\mathrm{W}$, WFR, and $\mathrm{WR}_{\mathrm{W}}$ produced larger leaves than those in $\mathrm{GH}$ or under $\mathrm{W}_{\mathrm{GH}}$ after 8 weeks (Fig. 4), only those acclimated under WFR produced a higher root $\mathrm{DM}$ and longer roots than in $\mathrm{GH}$ or under $\mathrm{W}_{\mathrm{GH}}$.

Others have shown positive rooting effects in response to FR radiation, which is thought to regulate adventitious root formation by inducing changes in auxin homeostasis and signaling (Christiaens et al., 2016). Christiaens et al. (2019) reported a higher root DM when chrysanthemum (Chrysanthemum morifolium) cuttings were grown under a PPFD of $60 \mu \mathrm{mol} \cdot \mathrm{m}^{-2} \cdot \mathrm{s}^{-1}$ supplemented with $60 \mu \mathrm{mol} \cdot \mathrm{m}^{-2} \cdot \mathrm{s}^{-1}$ of FR compared with monochromatic red or blue + red + FR radiation with a total photon flux density (PPFD + FR) of $60 \mu \mathrm{mol} \cdot \mathrm{m}^{-2} \cdot \mathrm{s}^{-1}$. The authors suggested that the beneficial rooting effect of FR radiation is associated with a shadeavoidance response that increases auxin biosynthesis (Christiaens et al., 2019). These auxins increase stem elongation and leaf area expansion and improve rooting success of cuttings. Accordingly, we found that transplants acclimated under WFR produced longer stems than those in GH and $\mathrm{W}_{\mathrm{GH}}$ (Table 3 ), and the differences were maintained between WFR and GH after 3 weeks of growth during the finish stage (Table 4). Transplants under $\mathrm{W}$ and $\mathrm{WR}_{\mathrm{W}}$ also produced longer stems than those in GH during acclimation and after the finish stage, suggesting that other factors beyond FR radiation affected stem elongation.

In addition to potential rooting advantages, several studies have reported growth benefits when growing transplants under different proportions of FR radiation. Some of those benefits include increases in shoot DM and early flower induction (Park and Runkle, 2017, 2018, 2019). Elkins and van Iersel (2020) evaluated 18 intensities of supplemental FR radiation on the growth and morphology of foxglove (Digitalis purpurea) seedlings. The authors were unable to identify a saturating photon flux density of FR radiation, as the overall growth responses were linear across the range of FR intensities evaluated (Elkins and van Iersel, 2020). Although they reported that FR had little to no effect on specific leaf area and seedling compactness, height increased by $38 \%$ as FR increased. This and other studies suggest that FR-induced increases in canopy size can enable plants to capture more radiation to drive photosynthesis and growth (Legendre and van Iersel, 2021). However, it is important to consider that although FR helps increase radiation interception and potentially, biomass accumulation, it typically induces stem elongation, which is generally undesirable in propagation.

Based on our results from Expt. 2 and the findings of others, supplementing PPFD with FR radiation has potential to improve growth and adventitious rooting of transplants (Tables 2-4). However, recommended intensities of FR to maximize rooting while maintaining compact growth are unknown, and those are likely to be species-specific. Further studies are needed to evaluate different intensities of FR radiation, enabling the differentiation from potential effects on leaf area expansion and stem elongation (Elkins and van Iersel, 2020) vs. hormonal effects on adventitious rooting (Christiaens et al., 2019). In addition, although there were no differences in chlorophyll and anthocyanin concentration, the obvious changes in leaf pigmentation observed in our study could be indicators of differences in the photosynthetic capacity of blueberry transplants in response to FR (Fig. 4), which should be further explored to better understand the potential to maximize productivity of indoor propagation with LEDs.

In conclusion, indoor acclimation offers significant opportunities to help reduce shrinkage, which is particularly beneficial for TC blueberry transplants that are highly susceptible to shrinkage during ex vitro acclimation in greenhouses. Growth responses to increasing PPFD during indoor acclimation were linear in most cases, suggesting that higher PPFDs could further increase subsequent transplant growth. Although treatment effects after finishing were generally similar among the PPFD treatments evaluated in Expt. 1, constantly providing higher PPFDs during indoor acclimation could help reduce the propagation cycle for blueberry transplants. Furthermore, increasing the PPFD over time with INCR had small growth effects but could prove to be an economical alternative for indoor acclimation of TC transplants, as it could help reduce the operational expense of providing sole-source lighting.

Our findings from Expt. 2 show that growth of indoor-acclimated transplants was generally greater than that in $\mathrm{GH}$ or under $\mathrm{W}_{\mathrm{GH}}$. However, spectral changes over time did not provide major growth advantages compared with constant radiation-quality treatments indoors. Transplants acclimated under WFR generally produced a higher shoot and root DM than those in $\mathrm{GH}$ or under $\mathrm{W}_{\mathrm{GH}}$, and these differences were maintained after 3 weeks of growth in the finish stage. Our findings suggest that supplementing PPFD with FR radiation has potential to improve growth and adventitious rooting of blueberry transplants. However, recommended intensities of FR to maximize rooting while maintaining compact growth are unknown. Further studies are needed to better understand rate-limiting steps during indoor propagation, particularly those in response to radiation quantity and quality. In addition, more work is needed to explain the relationship between leaf pigmentation and growth of blueberry transplants.

\section{Literature Cited}

Boldt, J.K., M.H. Meyer, and J.E. Erwin. 2014. Foliar anthocyanins: A horticultural review. Hort. Rev. 42:209-252, https://doi.org/10.1002/ 9781118916827.ch04.

Chandra, S., R. Bandopadhyay, V. Kumar, and R. Chandra. 2010. Acclimatization of tissue cultured plantlets: From laboratory to land. Biotechnol. Lett. 32:1191-1205, https://doi.org/ 10.1007/s10529-010-0290-0.

Christiaens, A., B. Gobin, and M.C. Van Labeke. 2016. Light quality and adventitious rooting: A mini-review. Acta Hort. 1134:385-393, https:// doi.org/10.17660/ActaHortic.2016.1134.50.

Christiaens, A., B. Gobina, J. Van Huylenbroeckb, and M. Van Labeke. 2019. Adventitious rooting of Chrysanthemum is stimulated by a low red:far-red ratio. J. Plant Physiol. 236:117-123, https://doi.org/10.1016/j.jplph.2019.03.008.

Currey, C.J., V.A. Hutchinson, and R.G. Lopez. 2012. Growth, morphology, and quality of rooted cuttings of several herbaceous annual bedding plants are influenced by photosynthetic daily light integral during root development. HortScience 47:25-30, https://doi.org/10.21273/ HORTSCI.47.1.25.

Davis, P.A. 2016. The use of light-emitting diode systems for improving plant propagation and production. Acta Hort. 1140:347-350, https:// doi.org/10.17660/ActaHortic.2016.1140.79.

Debnath, S.C. and J.A. Goyali. 2020. In vitro propagation and variation of antioxidant properties in micropropagated Vaccinium berry plants-a review. Molecules 25(4):788, https://doi.org $10.3390 /$ molecules 25040788 .

Elkins, C. and M.W. van Iersel. 2020. Supplemental far-red light-emitting diode light increases growth of foxglove seedlings under sole-source lighting. HortTechnology 30:564-569, https:// doi.org/10.21273/HORTTECH04661-20.

Faust, J.E., J.M. Dole, and R.G. Lopez. 2017. The floriculture vegetative cutting industry. Hort. Rev. 44:121-172, https://doi.org/ 10.1002/9781119281269.ch3.

Fisher, P.R., C. Gómez, Y. Zhang, and A. Goff. 2020. 5 Tips to improve indoor propagation of cuttings and tissue culture plants. Greenhouse Grower December issue. 5 Jan. 2021. <https:// www.greenhousegrower.com/crops/5-tips-toimprove-indoor-propagation-of-cuttings-andtissue-culture-plants/>.

Franklin, K.A. and G.C. Whitelam. 2005. Phytochromes and shade-avoidance responses in plants. Ann. Bot. 96:169-175, https://doi.org/ 10.1093/aob/mci165.

Gago, J., L. Martínez-Núñez, M. Landín, J. Flexas, and P.P. Gallego. 2014. Modeling the effects of light and sucrose on in vitro propagated plants: A multiscale system analysis using artificial intelligence technology. PLoS One 9:85989, https://doi.org/10.1371/journal.pone.0085989.

Gibson, K.E., A.J. Lamm, F. Masambuka-Kanchewa, P.R. Fisher, and C. Gómez. 2020. Identifying indoor plant propagation research and education needs of specialty crop growers. HortTechnology 30:519-527, https://doi.org/ 10.21273/HORTTECH04622-20.

Gould, K.S., K.R. Markham, R.H. Smith, and J.J. Goris. 2000. Functional role on anthocyanins in the leaves of Quintinia serrata A. Cunn. J. Exp. Bot. 51:1107-1115, https://doi.org/ 10.1093/jexbot/51.347.1107.

Greenhouse Grower. 2020. 8 Greenhouse technology trends for 2020. 2 Feb. 2020. <https:// www.greenhousegrower.com/technology/newwhitepaper-8-greenhouse-technology-trendsfor-2020/>

Guo, Y.-X., Y.-Y. Zhao, M. Zhang, and L.-Y. Zhang. 2019. Development of a novel in vitro rooting culture system for the micropropagation of highbush blueberry (Vaccinium corymbosum) seedlings. Plant Cell Tissue Organ Cult 139:615-620, https://doi.org/10.1007/s11240-019$01702-7$.

He, D. 2020. Transplant production in closed systems, Photosynthetic characteristics of vegetable and medicinal transplants as affected by the light environment, p. 313-318. In: T. Kozai, G. Niu, and M. Takagaki (eds.). Plant factory. 2nd 
ed. Elsevier Inc., London, UK, https://doi.org/ 10.1016/B978-0-12-801775-3.00019-6.

Hernández, R. and C. Kubota. 2014. Growth and morphological response of cucumber seedlings to supplemental red and blue photon flux ratios under varied solar daily light integrals. Scientia Hort. 173:92-99, https:// doi.org/10.1016/j.scienta.2014.04.035.

Hung, C.D., G.-K. Hong, S.K. Kim, K.-H. Lee, J.-Y. Park, M.-W. Nam, D.-H. Choi, and H.-I. Lee. 2016. LED light for in vitro and ex vitro efficient growth of economically important highbush blueberry (Vaccinium corymbosum L.). Acta Physiol. Plant. 38:1-9, https://doi.org/10.1007/s11738-016-2164-0.

Isutsa, D.K., M.P. Pritts, and K.W. Mudge. 1994. Rapid propagation of blueberry plants using ex vitro rooting and controlled acclimatization of micropropagules. HortScience 29:1124-1126, https://doi.org/10.21273/HORTSCI.29.10.1124.

Kumar, K. and I.U. Rao. 2012. Morphophysiologicals problems in acclimatization of micropropagated plants in-ex vitro conditions - a review. J. Ornam. Hort. Plants 2:271-283.

Legendre, R. and M.W. van Iersel. 2021. Supplemental far-red light stimulates lettuce growth: Disentangling morphological and physiological effects. Plants 10:166. doi. ORG/10.3390/PLANTS10010166.

Loach, K. and A.P. Gay. 1979. The light requirement for propagating hardy ornamental species from leafy cuttings. Scientia Hort. 10:217-230, https://doi.org/10.1016/0304-4238(79)90077-3.

Lopez, R.G. and E.S. Runkle. 2008. Photosynthetic daily light integral during propagation influences rooting and growth of cuttings and subsequent development of New Guinea impatiens and petunia. HortScience 43:2052-2059, https:// doi.org/10.21273/HORTSCI.43.7.2052.

Navidad, H. 2015. Impact of additional blue light in the production of small plants of Abies laciocarpa and Picea abies propagated by seeds and stem cuttings. Norwegian Univ. Life Sci., Ås, master's thesis.

Owen, W.G. and R.G. Lopez. 2018. Propagation daily light integral and root-zone temperature influence rooting of single-internode Pennisetum $\times$ advena culm cuttings. HortScience 53:176-182, https://doi.org/10.21273/HORTSCI12455-17.

Park, S.M., E.J. Won, Y.G. Park, and B.R. Jeong. 2011. Effects of node position, number of leaflets left, and light intensity during cutting propagation on rooting and subsequent growth of domestic roses. Hort. Environ. Biotechnol. 52:339-343, https://doi.org/10.1007/s13580-011-0163-z.

Park, Y. and E.S. Runkle. 2017. Far-red radiation promotes growth of seedlings by increasing leaf expansion and whole-plant net assimilation. Environ. Exp. Bot. 136:41-49, https:// doi.org/10.1016/j.envexpbot.2016.12.013.

Park, Y. and E.S. Runkle. 2018. Far-red radiation and photosynthetic photon flux density independently regulate seedling growth but interactively regulate flowering. Environ. Exp. Bot. 155:206-216, https://doi.org/10.1016/j.envexpbot.2018.06.033.

Park, Y. and E.S. Runkle. 2019. Blue radiation attenuates the effects of the red to far-red ratio on extension growth but not on flowering. Environ. Exp. Bot. 168:103871, https://doi.org/ 10.1016/j.envexpbot.2019.103871.

Phillips, G.C. and M. Garda. 2019. Plant tissue culture media and practices: An overview. In Vitro Cell. Dev. Biol. Plant 55:242-257, https://doi.org/10.1007/s11627-019-09983-5.

Pospísilová, J., I. Tichá, P. Kadleček, D. Haisel, and Š. Plzáková. 1999. Acclimatization of micropropagated plants to ex vitro conditions. Biol. Plant. 42:481-497, https:// doi.org/10.1023/A:1002688208758.

Pramuk, L.A. and E.S. Runkle. 2005. Photosynthetic daily light integral during the seedling stage influences subsequent growth and flowering of Celosia, Impatiens, Salvia, Tagetes, and Viola. HortScience 4:1336-1339, https:// doi.org/10.21273/HORTSCI.40.5.1336.

Randall, W.C. and R.G. Lopez. 2014. Comparisons of supplemental lighting from highpressure sodium lamps and light-emitting diodes during bedding plant seedling production. HortScience 49:589-595, https:// doi.org/10.21273/HORTSCI.49.5.589.

Rapaka, V.J., B. Bessler, M. Schreiner, and U. Druege. 2005. Interplay between initial carbohydrate availability, current photosynthesis, and adventitious root formation in Pelargonium cuttings. Plant Sci. 168:1547-1560, https:// doi.org/10.1016/j.plantsci.2005.02.006.

Richardson, A.D., S.P. Duigan, and G.P. Berlyn 2002. An evaluation of noninvasive methods to estimate foliar chlorophyll content. New Phytol. 153:185-194, https://doi.org/10.1046/ j.0028-646X.2001.00289.x.

Runkle, E. 2020. Indoor propagation. GPN Magazine, July issue. 4 Apr. 2021. <https:/gpnmag. com/article/indoor-propagation/ $>$.

Sáez, P., L.A. Bravo, M.I. Latsague, M.J. Toneatti, M. Sánchez-Olate, and D. Ríos. 2013. Light energy management in micropropagated plants of Castanea sativa, effects of photoinhibition. Plant Sci. 201-202:12-24, https://doi.org/10.1016/ j.plantsci.2012.11.008.

Steyn, W.J., S.J.E. Wand, D.M. Holcroft, and G. Jacobs. 2002. Anthocyanins in vegetative tissues: A proposed unified function in photoprotection.
New Phytol. 155:349-361, https://doi.org/ 10.1046/j.1469-8137.2002.00482.x.

Tombesi, S., A. Palliotti, S. Poni, and D. Farinelli. 2015. Influence of light and shoot development stage on leaf photosynthesis and carbohydrate status during the adventitious root formation in cuttings of Corylus avellana L. Front. Plant Sci. 6:973, https://doi.org/10.3389/fpls.2015.00973.

Torres, A.P. and R.G. Lopez. 2011. Photosynthetic daily light integral during propagation of Tecoma stans influences seedling rooting and growth. HortScience 46:282-286, https://doi.org/10.21273/ HORTSCI.46.2.282.

Trojak, M. and E. Skowron. 2017. Role of anthocyanins in high-light stress response. World Sci. News 81:150-168.

U.S. Department of Agriculture (USDA). 2018. Noncitrus fruits and nuts. 2017. Summary. 20 March 2019. <https://www.nass.usda.gov/ Publications/Todays_Reports/reports/ncit0618. pdf $>$.

Van Huylenbroeck, J.M. and J.D. Riek. 1995. Sugar and starch metabolism during ex vitro rooting and acclimatization of micropropagated Spathiphyllum Petite plantlets. Plant Sci. 111:19-25, https://doi.org/10.1016/0168-9452(95)04223-H.

Van Huylenbroeck, J.M., A. Piqueras, and P.C. Debergh. 2000. The evolution of photosynthetic capacity and the antioxidant enzymatic system during acclimatization of micropropagated Calathea plants. Plant Sci. 155:59-66, https://doi.org/ 10.1016/S0168-9452(00)00201-6.

Vieira, C.F., F.E.L. Carvalho, Y. Lima-Melo, C.P.S. Carvalho, M.C. Lima Neto, M.O. Martins, and J.A.G. Silveira. 2019. Integrative approach reveals new insights into photosynthetic and redox protection in ex vitro tobacco plantlets acclimatization to increasing light intensity. Biotech. Res. Innov. 3:59-72, https://doi.org/10.1016/j.biori.2020.04.001.

Wellburn, A.R. 1994. The spectral determination of chlorophylls a and b, as well as total carotenoids, using various solvents with spectrophotometers of different resolution. J. Plant Physiol. 144:307-313, https://doi.org/10.1016/ S0176-1617(11)81192-2.

Zimmerman, R.H. and O.C. Broome. 1980. Blueberry micropropagation. In: Proceedings conference on nursery production of fruit plants through tissue culture-application and feasibility. U.S. Dept. Agr. Sci. Edu. Adm., ARR-NE-11, p. 4447.

Zobayed, S. 2020. Transplant production in closed systems, Blueberry, p. 318-323. In: T. Kozai, G. Niu, and M. Takagaki (eds.). Plant factory. 2nd ed. Elsevier Inc., London, UK, https://doi.org/ 10.1016/B978-0-12-801775-3.00019-6. 